\title{
Não Transmissibilidade do Vírus do Amarelão do Meloeiro por Sementes
}

\author{
Antonio A. dos Santos, Francisco M. P. Viana, José E. Cardoso \& Julio C. Vidal \\ Embrapa Agroindústria Tropical, Cx. Postal 3761, CEP 60511-110, Fortaleza, CE, e-mail: apoliano@cnpat.embrapa.br
}

(Aceito para publicação em 12/07/2004)

Autor para correspondência: Antonio A. dos Santos

\begin{abstract}
Lack of transmission of the melon yellowing virus through seeds

A newly described melon (Cucumis melo) yellowing disease caused by a carlavirus has been occurring in the Brazilian Northeast since 1999. Attempts have been undertaken to understand its transmission through seeds. Despite its successful transmission by grafting and by whitefly, all attempts by seed transmission have failed.
\end{abstract}

O cultivo do meloeiro (Cucumis melo L.) é uma das atividades agrícolas de maior expressão econômica da Região Nordeste do Brasil, a qual responde por $99,3 \%$ da área plantada no país e cerca de $99,5 \%$ da produção nacional. Nessa região, destacam-se os Estados do Rio Grande do Norte e do Ceará, respondendo por mais de $80 \%$ da produção regional (Brasil, FrutiSéries, Ceará. Melão, 2. 2003). A expansão da área cultivada, aliada ao monocultivo intensivo, tem contribuído para a sobrevivência de patógenos e outros parasitas, além do aparecimento de novas doenças, como o amarelão, cuja agente causal é, possivelmente, um novo vírus do gênero Carlavirus ou da família Flexiviridae (Nagata et al., Arch Virol 150:379-387. 2005). Estudos recentes demonstraram que o referido vírus é transmitido pela mosca-branca, Bemisia tabaci biotipo B Bellows \& Perring (Santos et al., Fitopatologia Brasileira 27:211. 2002a), por enxertia (Lima et al., Fitopatologia Brasileira 27:7. 2002), e que o mesmo infeta cucurbitáceas nativas: bucha (Luffa cylindrica Roem.) e melão var. pepino, e cultivadas: abóbora (Cucurbita moschata Duch) 'Baiana Tropical', maxixe (Cucumis anguria L.); melancia [Citrullus lanatus (Thumb) Matsumi \& Nakai]; melão var. Cantaloupe 'Gaúcho', e abobrinha (Cucurbita pepo L.) var. caserta (Santos et al., Fitopatologia Brasileira 27:211-212. 2002b). Os vírus do gênero Carlavirus são, geralmente, transmitidos por afídeos de modo não persistente (Kitajima et al., Fitopatologia Brasileira 22:5-24. 1997). No entanto, o vírus do mosqueado do caupi (Cowpea wild mottle virus, CWMV) foi detectado em plantas de soja [Glycine max (L.) Merril] e de caupi [Vigna unguiculata (L.) Walp] oriundas de sementes de plantas com sintomas (Brunt \& Kenten, Annals of Applied Biology 74:67-75. 1972).

Objetivando verificar a transmissibilidade do vírus do amarelão do meloeiro por meio de sementes foi desenvolvido um trabalho em casa de vegetação, na Embrapa Agroindústria Tropical, em Fortaleza, Ceará, em 2003, no qual foram testados cinco lotes de 200 sementes do híbrido 'Gold Mine', um por vez, sementes essas colhidas de plantas com severos sintomas do amarelão. As sementes foram semeadas em vasos de polietileno de 101 de capacidade e, após a germinação, as plantas foram irrigadas diariamente, e adubadas duas vezes por semana com $2 \mathrm{~g}$ de uréia e $3 \mathrm{~g}$ de cloreto de potássio por vaso. As avaliações do experimento com objetivo de se identificar sintomas da doença, também, foram diárias, até que as plantas completassem 40 dias de idade. Após esse período, as plantas eram eliminadas e um novo lote era semeado até que se completou o teste das 1.000 sementes. Os resultados demonstraram que o vírus do amarelão não foi transmitido pelas sementes, uma vez que nenhuma das 1.000 plantas avaliadas, resultantes de sementes retiradas de frutos infetados, apresentou sintomas da doença durante o período de observação (40 dias após o plantio). Sabe-se que plantas ainda jovens, com três ou quatro dias de idade, quando infetadas por meio da moscabranca, mostram os sintomas típicos do amarelão já a partir dos 20 dias de idade (Santos et al., Fitopatologia Brasileira 27:211-212. 2002a), enquanto uma virose causada por vírus transmitido por sementes, os sintomas surgem nas plantas poucos dias após a germinação. Portanto, a ausência de sintomas nas plantas de meloeiro testadas neste trabalho permite concluir que o vírus do amarelão do meloeiro não é transmitido por sementes. 